\title{
The Role of Jambi Malay Traditional Institutions in the Seloko Oral Traditions of the Jambi Culture in Maintaining the Advancement of Culture
}

\author{
Muhammad Dwi Kurniadi', Zulkarnain ${ }^{2}$ \\ ${ }^{1,2}$ Postgraduate Program in History Education, Faculty of Social Sciences, Universitas Negeri Yogyakarta, \\ Indonesia \\ Muhammad0077pasca.2019@student.uny.ac.id,zulkarnain@uny.ac.id
}

Abstract

The purpose of writing this scientific article is to gain an understanding of the oral tradition of the Javanese traditional seloko adat used in Javanese Malay weddings, whose problem formulation includes: (1) What is the oral tradition? (2) What is Jambi adat seloko? (3) How are the efforts of the Jambi provincial customary institutions to maintain the advancement of culture? To answer these three problems the writer used a qualitative approach with the literature study method that collected several articles from previous research and conducted interviews with several cultural figures in Jambi Province. From this research, it was found that one of the 10 elements of culture, namely the oral tradition, is found in Jambi under the name Seloko where it is an oral tradition that contains advice, guidelines for life.
Keywords

oral traditions; Seloko adat Jambi; cultural advancement

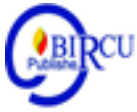

\section{Introduction}

The number of cultural elements in each region in Indonesia is something of pride. Especially in Jambi Province, it has an oral tradition culture in the form of traditional Seloko, Seloko adat is an oral tradition commonly used in weddings and traditional events as the opening of an event containing advice and moral values.

Nowadays, along with the times, of course the pattern of people's lives also develops, old habits are also slowly shifting the position of old habits. The development of this era certainly also touched on the position of culture in Indonesia which then led to many efforts in maintaining its culture, such as in Jambi province itself, along with the development of all aspects such as technology and the lifestyle of the people making the existing culture slowly fade.

Quoted from Law number 5 of 2017 concerning cultural advancement article 1 point 3 which states that the advancement of culture is an effort to increase cultural resilience and contribution of Indonesian culture in the midst of world civilization through the protection, development, utilization and fostering of culture. Based on the law which explains the advancement of culture, it can be concluded that the advancement of culture is an attempt to actualize a culture so that it remains in an existence that cannot be shifted by other things even though the present development is due to the increasing influence of world civilization, even the advancement of culture itself is also expected can position culture in the top position or strata with the protection, development, utilization and fostering of culture towards a culture itself. 
Based on the author's analysis, there are facts that are found that the position of culture itself has begun to fade, such as one of which is the oral tradition which is one form of the ten elements of culture that exist, for Jambi itself there are problems that cause fading and even the loss of an oral tradition which is one of the elements of culture, for example Seloko Adat which is a form of oral tradition in Jambi.

\section{Research Methods}

The method used in writing this article is literature study. This literature study method is known as a data collection method based on books, scientific articles, journals, and written sources that have relevance to the problems being studied. Researchers analyzed the data obtained through a descriptive qualitative data analysis strategy (Sugiyono, 2014: 114). Then John Creswell (2016: 4) also said that descriptive qualitative research is a way to explore and reveal meanings that are considered to come from social problems. By utilizing documentation to gather information that is relevant and related to the problem to be studied.

In line with the above statement, Zed (2014) states that in library research, literature search is not only for the initial step of preparing a research framework, but at the same time utilizing library sources to obtain research data. This literature review aims to build and construct a stronger conception based on relevant and ever conducted empirical research. In this study, the researchers mapped books, research results published in articles and theses whose studies were related to oral traditions, traditional seloko, and cultural advancement.

The stages carried out by the researcher follow Bungin's (2010: 264) opinion as follows: (1) collecting initial data such as books, scientific articles, journals, and other written sources relevant to the theme of the study, (2) processing the data by describing In brief, the correlation between categories analyzed through data reduction, (3) draw preliminary conclusions that are temporary and can change if strong facts are found in data collection, (4) test the validity of research results by triangulation of data sources, and (5) ) drawing conclusions on research results.

\section{Discussion}

Seloko adat which has become a medium for oral literacy or what is called an oral tradition has always been thick with cultural and educational values, including moral values. The results of the writing of this article are compiled based on a research formula, which describes the oral tradition, the Javanese traditional seloko, and the efforts of the Javanese provincial customary institutions to maintain the Javanese traditional seloko through cultural advancement.

\subsection{Oral Tradition}

Oral tradition is any discourse that is conveyed orally, following the methods or customs that have been formed in a society. According to Pane (2020) tradition is something that is passed down from the heritage of the ancestors to the next generation in a relay descends performed by the indigenous communities that have become deeply entrenched the culture in life. The views of modern humans, tradition has always associated as outdated (Lubis in Amri, 2018). The content of this includes various things: various types of stories or expressions of celebration or ritual. The stories told orally vary 
widely. Sedyawati (1995: 5) Oral tradition also includes matters relating to literature, language, history, biographies, and various knowledge and other types of art that are conveyed by word of mouth by the public. . This is in line with Pudentia's (1999: 32) statement which explains the essence of orality which explains that oral tradition does not only come from folk tales, puzzles, proverbs, folk songs, mythology, and legends as generally conveyed by people. However, Oral tradition is also related to the cognitive system of a culture, such as: history, medical law, and it can be concluded that oral tradition is all discourse that is spoken / passed down from generation to generation, including the oral and the literal ones. " In several places, the relevance of oral tradition writing into written manuscripts, as has been explained in the explanation above, certainly has different backgrounds. One of them is a form of preservation of values that are considered important that must be given and introduced to future generations. There is much debate about how to distinguish oral traditions from oral literature, according to a cultural observer from Jambi province (Nukman, interview, 24 September 2020) said that what is considered an oral tradition is the activity that the community follows from being oral and becoming a habit regulated in adat. However, if it makes a text that is spoken then it is oral literature, on the grounds that a caste work means it has an educational purpose because there are several words that must be interpreted for good clarity which contain the wisdom of society. So, according to the explanation that has been given by the oral tradition, knowledge that is passed down from generation to generation orally can also be in the form of works of art and customary law that is sustainable in the cultural process can also be sourced from traditional literary works that are conveyed orally and live in a historical aesthetic context social, ethical, organizational structure and sustainable moral values in a dynamic process of cultural development. Then, for the province of Jambi has an oral tradition in the form of traditional seloko, petatah-petitih, and patun which have been tried to be made into a literary work by the Jambi provincial customary institutions.

\subsection{Jambi Traditional Seloko}

Seloko adat is a type of culture in the form of an oral tradition in Jambi. traditional seloko. This traditional seloko is usually used in ceremonial communication and other expressions (M. Karim 2017: 2). Expressivity which means the ability to express or the willingness to express something, seloko is used in celebrations such as weddings and is also used in traditional institution events, and is also used in customary decision-making discussions such as customary congregations. Seloko adat contains cultural values, both in the form of life values, moral values, legal values, and so on. Seloko can also be used as a means of consolidating these cultural values. As a manifestation of cultural values, Seloko adat contains a cultural value system consisting of conceptions that are considered very valuable in social life.

Seloko adat is one of the traditional literary works of Jambi Malay which is oral in nature which is usually expressed in traditional ceremonies and sometimes as a medium of communication in everyday life. It is a text or texts that express feelings, thoughts, beliefs, messages, information, and customary provisions using the traditional Jambi Malay language. (A.Gafar, 2012: 44-45) Seloko is a traditional expression that contains advice, mandate, which is conveyed by traditional leaders orally to provide guidance for the safety of community members in social life and life. Seloko is a part of literature called an oral tradition which has cultural values in every social activity related to customs used in all aspects of life, especially in the implementation of the Jambi community's traditional wedding ceremony. However, along with the development of science and technology, this form of oral tradition rarely gets attention. Permissive values, or in other words, attitudes 
and views that allow and allow everything make them shifted dramatically. As in cases found in the field in the form of a wedding celebration because of this permissive attitude, the traditional seloko is not too important for the Javanese Malay community to not use it anymore, in addition to the actors who sing the oral tradition in the form of traditional Seloko Parents. The result of human interpolation made this literary form slowly disappear. Along with the development of science and technology, this form of oral tradition rarely gets attention. Permissive values, or in other words, attitudes and views that allow and allow everything make them shifted dramatically. As in cases found in the field in the form of a wedding celebration because of this permissive attitude, the traditional seloko is not too important for the Javanese Malay community to not use it anymore, plus the actors who sing the oral tradition in the form of traditional seloko parents. The result of human interpolation made this literary form slowly disappear along with the development of science and technology, this form of oral tradition rarely gets attention. Permissive values, or in other words, attitudes and views that allow and allow everything make them shifted dramatically. As in cases found in the field in the form of a wedding celebration because of this permissive attitude, the traditional seloko is not too important for the Javanese Malay community to not use it anymore, in addition to the actors who sing the oral tradition in the form of traditional seloko parents. The result of human interpolation makes this literary form slowly disappear. Permissive values, or in other words, attitudes and views that allow and allow everything make them shifted dramatically. As in cases found in the field in the form of a wedding celebration because of this permissive attitude, the traditional seloko is not too important for the Javanese Malay community to not use it anymore, in addition to the actors who sing the oral tradition in the form of traditional seloko parents. The result of human interpolation made this literary form slowly disappear. Permissive values, or in other words, attitudes and views that allow and allow everything make them shifted dramatically. As in cases found in the field in the form of a wedding celebration because of this permissive attitude, the traditional seloko is not too important for the Javanese Malay community to not use it anymore, in addition to the actors who sing the oral tradition in the form of traditional seloko parents. The result of human interpolation made this literary form slowly disappear. As in cases found in the field in the form of a wedding celebration because of this permissive attitude, the traditional seloko is not too important for the Javanese Malay community to not use it anymore, plus the actors who sing the oral tradition in the form of traditional seloko parents. The result of human interpolation made this literary form slowly disappear. As in cases found in the field in the form of a wedding celebration because of this permissive attitude, the traditional seloko is not too important for the Javanese Malay community to not use it anymore, plus the actors who sing the oral tradition in the form of traditional seloko parents. The result of human interpolation made this literary form slowly disappear.

It was emphasized (M.Karim, 2017: 3) that shifting values, changing ways of life, changing generations, developing science, and because of its oral nature, made the seloko tradition fade away. So, it causes less Malay people in Javanese to communicate using traditional seloko, it's just that certain people like (ninik mamak, elder tengganai, cunning clever )who are still memorized and skilled in shops (A.Armida, 2010: 126). In line with the opinion of the author's interview with Lukman and Datuk Azra'i (an employee of the Jambi language office who deals with literature and head of the Jambi provincial customary institution) they agree that the traditional seloko should be in the form of an oral tradition which is one of the ten elements. Culture must be recorded in the form of oral literature and there must be a generation so that a culture does not just disappear. 
The following is a form of part of the oral tradition in the form of the Javanese traditional seloko which is carried out in a ceremonial event sung by seloko actors which contains advice for safety and life for the community.

live a fortune.

Beautiful season when it's good,

Teluk Tenang Rantau Completed, Padi

Becomes

To a keno snack,

To the land of the keno snare,

Behind the house of windfall,

Naek to the house of the child he was born,

To the kitchen lemang la stretched out,

Kerbaunyo fat mudo grass,

Aek clear tame fish,

What ado want,

Apo dicinto apo bulih,

Lips with a smile,

The virgins were brought laughing,

The dimple brought laughter.

Which contains the value of teaching the purpose of our way of life in this world, the aspirations and hopes that must be achieved, which in Javanese Malay language is often conveyed in the form of seloko above containing philosophical and meaningful messages conveyed through beautiful and soothing sentences. . Followed by (S. Ramli, 2018: 8) basically sentences containing life's advice, none other than containing moral and religious messages that are conveyed in interesting and neat language.

There are five functions seloko also has a function and focuses on the pragmative function. Seloko pragmative function is divided into five in (M.Karim, 2017: 12-17):

1. Infomational function.

For example, describing how the information function in shop (seloko contains various information)

2. Expressive function.

How does seloko itself become a medium for pouring out the thoughts, feelings, attitudes, or beliefs of speakers. It is as if the seloko describes the inner voice of the speaker or speaker.

3. The directive function.

A seloko contains various directions, guides, or maybe in the form of instructions to the people or speakers (conveying messages, advice, teaching points / educational values).

4. Aesthetic function

Seloko is part of folk poetry, of course, things like that contains beauty values.

5. Fatigue function

This function is oriented to the channel used in communication, it can be seen from the point of view of contact between speaker and listener. That is, the language used functions to build relationships, maintain, show unity. This function also makes the text intact. 


\subsection{The Efforts of the Jambi Provincial Customary Institutions to Maintain the Javanese Traditional Seloko}

Based on the provincial regulation of Jambi Province number 2 of 2004 concerning Jambi Malay traditional institutions, Chapter II regarding the principles, objectives, and scope, Article 2 reads that Jambi Province's Traditional Malay Traditional Institution is based on Pancasila, the 1945 Constitution of the Republic of Indonesia, and customary values and Religion is Adat with syara 'jointed, Syara with Kitabullah jointed. Then the LAM (traditional Malay institution) has the aim of exploring, fostering, preserving, maintaining and developing Malay customary values and socio-cultural values as a basis for strengthening and strengthening the identity of the Javanese Malay community and protecting the traditional and constitutional rights of indigenous peoples and the sociocultural values of Jambi Malay for the benefit of improving the physical and spiritual welfare of the Javanese Malay community. Then the scope of this regional regulation,

Customary institutions do not stand alone, but must be able to work together with various other government agencies and agencies at various lines and levels, from village to provincial level (A.Armida, 2010: 114). As long as he was elected as chairman of the traditional Malay traditional institution in Jambi province, he continued to strive to preserve adat and also strengthen institutions that were also considered down to the smallest scope such as RT $\square$ so that the customary process up to the smallest structure is monitored according to the determined values.

The resource person also provided an explanation for maintaining the advancement of culture as described in the law on cultural advancement to protect, develop, utilize, and foster culture, in which case the Javanese traditional institution has made a book entitled the principles of adat Sepucuk Jambi Nine headmen which divided into six volumes, and a section for Javanese traditional literature which explains the pantun, petatah-petith and seloko there are volume 3 as a form of cultural protection and clearly found 287 seloko, 4 petitih quotes and 34 existing patun.

In the form of developing Javanese traditional institutions, Jambi is still aggressively conducting research to determine the development of cultures in Jambi Province in order to protect the existing cultures in Jambi. Furthermore, in the form of utilization so as not to be swallowed up by the era of the Malay traditional institutions, Jambi is still often aggressively using values that contain cultural elements and customary principles in ceremonial celebrations to the smallest institutional events. And also the Javanese traditional institution has carried out cultural development so that the content of cultural values is well preserved by cultural actors. Then, customary institutions also hold free trainings for young people who want to learn oral tradition culture in the form of traditional seloko.

\section{Conclusion}

Oral tradition is one of the ten cultural elements in Indonesia, which are found in quite a large number in every province in Indonesia, especially in Jambi Province itself has an oral tradition in the form of seloko adat jambi, an oral tradition that contains life values and values such as advice, guidelines for life, containing moral teachings are also used in customary events.

Then along with the development of the times to keep this oral tradition culture from fading, of course, as a Malay traditional institution, it has carried out several actions that are deemed necessary to maintain this culture. 


\section{References}

Amri, Y.K. (2018). Mangupa; An Oral Tradition of Angkola Community. Budapest International Research and Critics Institute-Journal (BIRCI-Journal) Vol I (2): 5161.

Armida, A. (2010). Eksistensi Lembaga Adat: Studi Kasus Lembaga Adat Melayu Jambi Tanah Pilih Pasko Batuah Kota Jambi dan Tinjauan Kritis Terhadap Perda No. 5 Tahun 2007. Kontekstualita: Jurnal Penelitian Sosial Keagamaan, 25(1), 37089.

Creswell, J. W. (2016). Research Design : Pendekatan Metode Kualitatif, Kuantitatif dan Campuran (Keempat). Pustaka Pelajar.

Gafar, A. (2012). Peranan seloko dalam upacara adat perkawinan masyarakat di Kota Jambi. Pena: Jurnal Pendidikan Bahasa dan Sastra, 2(1).

Karim, M. (2017). Seloko Adat Ulur Antar Serah Terima Adat Pada Pernikahan Adat Melayu Jambi: Kajian Bentuk dan Fungsi. Pena: Jurnal Pendidikan Bahasa dan Sastra, 6(2).

Lembaga Adat Provinsi Jambi.2001. Pokok-Pokok Adat Pucuk Jambi Sembilan Lurah, Sejarah Jambi. Jambi: Lembaga Adat Provinsi Jambi.

Pane, A., et al. (2020). The Performance of Mangupa Tradition in Angkola Custom, Medan, Indonesia. Budapest International Research and Critics Institute-Journal (BIRCI-Journal) Vol 3 (3): 1747-1757.

Peraturan Daerah (PERDA) Provinsi Jambi No. 2 Tahun 2014. Lembaga Adat Melayu Jambi.

Ramli, S. (2018). Filosofi dan Aktualisasi Seloko Adat di Bumi Tanah Pilih Pusako Betuah Kota Jambi. Titian: Jurnal Ilmu Humaniora, 2(1), 1-28.

Sedyawati, Edi (1995), "Kedudukan Tradisi Lisan dalam Ilmu-ilmu Sosial dan Ilmu-ilmu Budaya", dalam Warta ATL. Jurnal Pengetahuan dan Komunikasi peneliti dan Pemrhati Tradisi Lisan. Edisi II Maret. Jakarta: ATL.

Sugiyono. (2014). Memahami Penelitian Kualitatif. Alfabeta.

Undang-Undang Republik Indonesia Nomor 5 Tahun 2017 Tentang Pemajuan Kebudayaan.

Zed, M. (2014). Metode Penelitian Kepustakaan (Pertama). Yayasan Obor Indonesia.

\section{Interview}

Nukman, 24 September 2020 Pengamat kebudayaan Provinsi Jambi

Lukman, 24 september 2020 Pegawai Kantor Bahasa Provinsi Jambi

Datuk Azra'I, 14 Juli 2020 Ketua Lembaga Adat Melayu Provinsi Jambi 